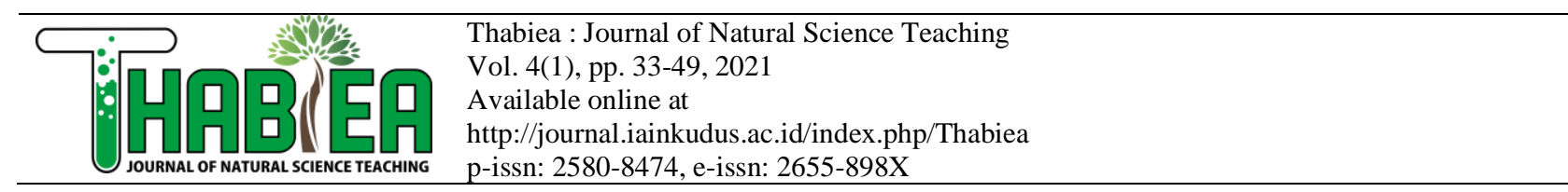

\title{
Review Analysis of Video Blogging, Ethnoscience and Social Media Literacy in the Era of the Industrial Revolution 4.0
}

\author{
Indah Beti Lestari ${ }^{*}$, Sudarmin ${ }^{2}$, Ellianawati ${ }^{3}$, Wiyanto ${ }^{4}$, Woro Sumarni ${ }^{5}$ \\ Science Education Program, Postgraduate Program, Semarang State University, \\ Jalan Kelud Utara III Petompon Gajahmungkur Semarang 50237, Central Java, Indonesia \\ *Correspondence: indahbetilestari@students.unnes.ac.id
}

\begin{tabular}{|c|c|}
\hline & Abstract \\
\hline $\begin{array}{l}\text { Keywords: } \\
\text { Review analysis } \\
\text { Video blogging } \\
\text { Ethnoscience } \\
\text { Social media literacy } \\
\text { Industrial revolution } \\
4.0\end{array}$ & $\begin{array}{l}\text { Research on Vlogs, ethnoscience, and social media literacy, is one of the trends in the } \\
\text { era of the industrial revolution } 4.0 \text {, so it is exciting to research. However, scientific } \\
\text { studies are still relatively new and rare. A systematic review is not yet available. Thus, } \\
\text { the purpose of this study was to analyze the review content of synthesized articles with } \\
\text { a focus on the study of the authors' origin, aims, method variations, and findings. This } \\
\text { research's data collection method adopted the PRISMA design, consisting of four steps: } \\
\text { identification, screening, eligibility, and inclusion. Article searches are carried out using } \\
\text { the publish or perish application directly linked to Google Scholar search. The total } \\
\text { number of articles found was } 2971 \text { articles in the period } 2016 \text { to } 2020 \text {. This study was } \\
\text { decided to review } 25 \text { articles with the distribution of } 8 \text { Vlog, } 6 \text { ethnosciences, and } 11 \\
\text { social media literacy. The results showed that (1) Indonesia was the country that was } \\
\text { ranked first out of nine countries on the topics of Vlog by } 75 \% \text { and ethnoscience topics } \\
\text { by } 67 \% \text {, (2) the purpose of the research is on average testing, finding and developing } \\
\text { topics with other variables, (3) the research methods also used varied, including } \\
\text { descriptive qualitative, quasi-experimental, exploratory, survey, literature review, and } \\
\text { R\&D, (4) The findings indicate that these topics are interesting to study because they } \\
\text { have a positive effect on learning, increasing learning motivation, self-confidence, } \\
\text { speaking skills, understanding concepts, and critical thinking skills, innovative, creative } \\
\text { to the entrepreneurial character. }\end{array}$ \\
\hline
\end{tabular}

To cite this article:

Lestari, I. B., Sudarmin, Ellianawati, Wiyanto, Sumarni, W. (2021). Review Analysis of Video Blogging, Ethnoscience and Social Media Literacy in the Era of the Industrial Revolution 4.0. Thabiea : Journal of Natural Science Teaching, 4(1), 33-49.

\section{Introduction}

The era of the Industrial Revolution 4.0 has had a noticeable impact in all fields. Fundamentally, this revolution has changed the way humans think, live, and relate to one another (Prasetyo \& Trisyanti, 2019). How to live and relate to one another can never be separated from the role of technology. The development of digital technology in the current Industry 4.0 era has brought changes and influenced various aspects of human life, including education (Putrawangsa \& Hasanah, 2018). One of the most dominant changes in digital technology in education is in the teaching and learning process.

Moreover, the Covid-19 pandemic has for months required the government to make policies to close schools, colleges and universities to reduce the coronavirus spread. Closing schools does not mean the learning process has stopped. For the learning process to continue, and students get knowledge according to the government's curriculum, the role of technology is needed. 
Online is felt to be able to answer the problems experienced by educational institutions during the Covid-19 pandemic. Information technology is a solution to implementing online learning (Suni Astini, 2020). The learning system is implemented through a computer device (PC / laptop) or Android cellphone connected to an internet network connection. However, online learning will not work if there are no facilitating media. The existence of learning media as a tool in the learning process is a fact that cannot be denied (Irwandani \& Juariyah, 2016). Therefore, we need media that can facilitate students' learning and facilitate teachers in delivering learning material. Besides, this media must also motivate students to continue learning without feeling bored during online learning. Learning media plays an essential role in making learning activities more effective and efficient (Jauhari, 2018). One of the media that is effectively used in online learning is video blogging or Vlogs.

Research conducted by Irwandani et al. (2019), the YouTube video blog channel with the STEM approach, is suitable as an alternative media for senior high school students' online learning. According to Hibra et al. (2019), Vlog is a form of activity carried out in video recordings or several images combined with sound, pictures, or other animations. So, Vlog can be said to be an audio-visual-based media. It is similar to other videos but has specific themes with particular objects and is packaged in attractive images uploaded on YouTube, which can be watched online or offline (M. Sari, 2020). Making a Vlog is also relatively easy because it only relies on recording devices, and talking about personal daily life is classified as a Vlog (David et al., 2017).

Research on Vlogs is exciting because Vlog has become a trend both among children and adults. Even on YouTube recently, many new accounts have sprung up. People are becoming Vlogger (as a Vlog maker) with various content from comedy, traveling, tutorials, styles, tips, and tricks to non-educational content. However, harmful content has millions of viewers, indicating that people have not used social media wisely. Social media literacy is needed to suppress harmful content with educational content. In education, social media application in learning is increasing and is recognized as a critical skill for teachers (Forbes, 2017). With social media, teachers can share, discuss and collaborate in teaching.

Along with the development of Vlogs and social media literacy in the era of industrial revolution 4.0, culture, customs, and local wisdom are the hallmarks of a sinking nation. Cultural science is rarely applied in learning, so many students do not see their own culture (Sumarni et al., 2020). The nation's local knowledge is not lost; the Vlog content must be presented with ethnoscience. Ethnoscience can be integrated into learning in schools with various learning themes. In addition to preserving local culture, ethnoscience learning is considered to improve student's quality of education and character (Sukesti et al., 2020). Sudarmin et al. (2019) also found that the learning model of natural culture and creativity can be creative, innovative, diligent, and characterize national culture. So, it is not surprising that research on Vlogs, ethnoscience, and social media literacy are research topics that are also of great interest to researchers. These topics are currently becoming a trend among the general public as well as researchers. Since 2016, these topics have coloured web search engines that can be accessed freely to find full-text research articles in the last five years.

However, the scientific study of Vlogs, ethnoscience, and social media literacy are still relatively new; detailed information is still rare. So far, no systematic review is available either. Therefore, it is necessary to conduct a literature review to reveal the scope of research on Vlog, 
ethnoscience, and social media literacy from 2016 to 2020 in the era of the industrial revolution 4.0. Thus, this systematic literature review analysis study analyzes the review content of synthesized articles focusing on studying the author's origin, aims, method variations, and findings.

\section{Method}

This study examines the scope of research in Vlog, ethnoscience, and social media literacy systematically. This systematic review was carried out using a modified procedure adopting the PRISMA (Preferred Items for Systematic Reviews and Meta-Analysis) design, which consists of four steps: identification, screening, eligibility, and inclusion (Wiyanto et al., 2020). The total number of articles found was 2971 articles in the period 2016 to 2020. This study was decided to review 25 items based on four steps in the systematic literature review analysis. The flow chart of the research procedure in this study is shown in Figure 1.

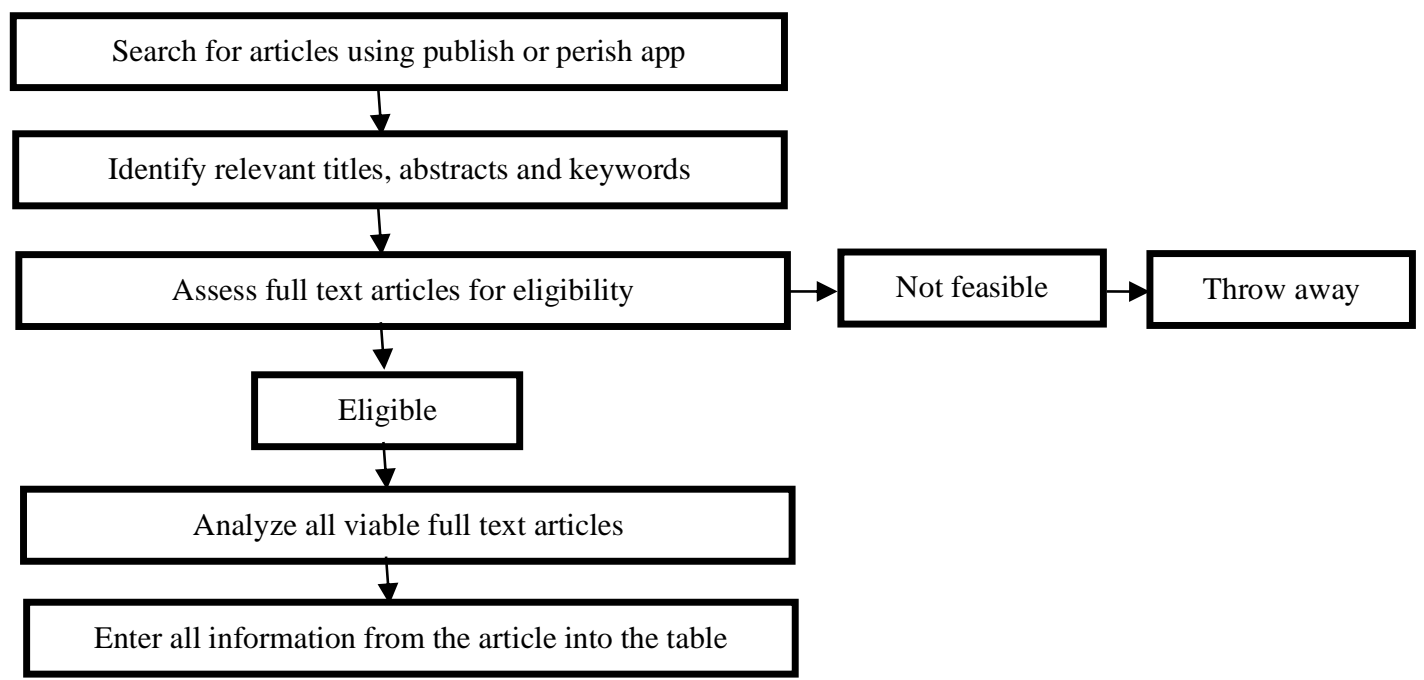

Figure 1. The procedure of systematic literature review analysis

The first stage is the identification, and article searches are carried out using a publish or perish application directly linked to Google Scholar search based on the keywords used. Keywords entered in the search box included video blogging or Vlogs, ethnoscience, and social media literacy, limiting articles from 2016 to 2020. When keywords are entered, hundreds of articles will appear on the publish or perish application screen. At this stage, reports will be identified based on publication limits. Articles published between 2016 and 2020 are eligible to enter the second stage, while articles outside the publication year are discarded. In addition to the limitations of the article's publication, themes are also identified based on the title, abstract, keywords, and topics. Topics relevant to this research are included, while issues that are not suitable are discarded. At this stage, the articles produced tend to be broad. Then it needs to be filtered again at a later stage.

The second stage is filtering, where all articles that have been identified based on the title, abstract, and keywords relevant to the topic discussed are downloaded. Then the paper is assessed based on the complete content of the article to get the feasibility of whether the form is still used or discarded. Full-text articles were scanned to check the suitability of the topic for 
research purposes. Papers of the 'editor,' 'comments,' 'response,' 'book chapter,' and 'book reviews' types were excluded from the analysis. Full-text articles written in 'non-English languages' were also excluded. Those irrelevant articles are removed from the downloads folder.

In the third stage of eligibility, all articles that have been filtered and declared eligible are put in one folder based on keywords. Items about Vlogs are placed in the Vlog folder, ethnoscience, and social media literacy. Then all articles are worth analyzing and studying to conclude.

The fourth step is to enter all the required information from all eligible articles into the table as metadata. The paper sections included in the table include the author's name, year, author's origin, purposes, research topic/focus, methods used, and findings in the study. All eligible articles were studied and analyzed to get a synthesis or conclusion.

Analysis was carried out, including noting the author's name, to find out the authors who contributed to writing articles on the topics discussed. In addition, the year of publication is also recorded to find out when the research began to be published until it finally became a trend.

The nationalities of the authors were analyzed and assessed quantitatively to indicate the country's rank of publication. The author's citizenship contribution score is calculated using the following formula:

$$
\% \text { Nationality of the author }=\frac{\text { Number of articles published in that country }}{\text { Total of all analyzed articles }} \times 100 \%
$$

The author's goals were obtained by analyzing each article's diversity of research objectives, from which variety was classified based on similarities and differences in objectives. Similar research objectives were taken and concluded to be a growing trend among writers. The topic/focus of the research is also recorded to find out the distribution of the topics most interested by the author. The research method was analyzed to determine the distribution of the methods used by the author in researching the topics discussed. Then from the technique used, the results are compared with other methods used by other authors. The results of the research are focused on what the author finds from his study. Whether the author finds a good thing or not, in which part of the article the author finds goodness, for example, if the best research method is found using research and development ( $R \& D$ ) methods, then research and development will be carried out on these topics These findings will later be used as a literature review to conduct further research related to the issues discussed.

\section{Results and Discussion}

Article searches are carried out through the publish or perish application directly linked to Google Scholar search and for publication is limited to the period 2016 to 2020. The comprehensive search was 2971 articles out of 3 keywords entered---the first keyword by writing "Vlog" in the keywords column and found 987 items. The second keyword was written "ethnoscience" in the keywords box and resulted in 992 articles. The third keyword by writing "social media literacy" and also found 992 items. Of the 2971 articles found, it was decided to review 25 items with 8 pieces on Vlogs, 6 articles on ethnoscience, and 11 articles on social media literacy topics. The 25 items that have been studied are presented in Table 1. 
Table 1. Article data reviewed

\begin{tabular}{|c|c|c|c|c|c|c|}
\hline No & $\begin{array}{c}\text { Writer's } \\
\text { name }\end{array}$ & Year & $\begin{array}{l}\text { Author } \\
\text { Origin }\end{array}$ & Purpose & Method & Findings \\
\hline \multicolumn{7}{|c|}{ Video Blogging or Vlogs (8 articles) } \\
\hline 1 & $\begin{array}{l}\text { Christelle } \\
\text { Combe and } \\
\text { Tatiana } \\
\text { Codreanu }\end{array}$ & 2016 & French & $\begin{array}{l}\text { Describe and analyze } \\
\text { informal learning } \\
\text { communication using } \\
\text { vlogs }\end{array}$ & Qualitative & $\begin{array}{l}\text { Vloggers are highly } \\
\text { supported by peers to share } \\
\text { knowledge and comment on } \\
\text { an everyday basis }\end{array}$ \\
\hline 2 & Pramita Sari & 2017 & Indonesia & $\begin{array}{l}\text { Increase students' } \\
\text { motivation and } \\
\text { confidence to speak }\end{array}$ & Quantitative & $\begin{array}{l}\text { The use of Vlogs on } \\
\text { Youtube Channels increases } \\
\text { student motivation and self- } \\
\text { confidence }\end{array}$ \\
\hline 3 & $\begin{array}{l}\text { Mustafa } \\
\text { Fidan, Murat } \\
\text { Debbağ }\end{array}$ & 2018 & Turkey & $\begin{array}{l}\text { Facilitating students to } \\
\text { create a Vlog }\end{array}$ & Qualitative & $\begin{array}{l}\text { Vlogs are helpful for } \\
\text { personal, professional, } \\
\text { social, and technical } \\
\text { reasons. }\end{array}$ \\
\hline 4 & $\begin{array}{l}\text { Bics Al Hibra, } \\
\text { Luqman } \\
\text { Hakim, Tri } \\
\text { Sudarwanto }\end{array}$ & 2019 & Indonesia & $\begin{array}{l}\text { Finding out the } \\
\text { feasibility of Vlog- } \\
\text { based learning media }\end{array}$ & $\begin{array}{l}\text { Research and } \\
\text { development }\end{array}$ & $\begin{array}{l}\text { Vlog is declared worthy as } \\
\text { a learning medium }\end{array}$ \\
\hline 5 & $\begin{array}{l}\text { Arumsari, } \\
\text { Saly Kurnia } \\
\text { Octaviani, } \\
\text { Suryanti } \\
\text { Galuh } \\
\text { Pravitasari }\end{array}$ & 2019 & Indonesia & $\begin{array}{l}\text { Describe the } \\
\text { relationship between } \\
\text { learning motivation and } \\
\text { language skills using } \\
\text { Vlog }\end{array}$ & $\begin{array}{l}\text { Qualitative } \\
\text { descriptive by } \\
\text { presenting the } \\
\text { form of } \\
\text { statistical data }\end{array}$ & $\begin{array}{l}\text { High student motivation to } \\
\text { realize results in high } \\
\text { speaking skills scores }\end{array}$ \\
\hline 6 & $\begin{array}{l}\text { Sharfina } \\
\text { Karamina, } \\
\text { Thriwaty } \\
\text { Arsal, \& } \\
\text { YYFR } \\
\text { Sunarjan }\end{array}$ & 2019 & Indonesia & $\begin{array}{l}\text { Analyze the role of the } \\
\text { teacher } \\
\text { in utilizing vlog-based } \\
\text { learning media }\end{array}$ & $\begin{array}{l}\text { Qualitative } \\
\text { descriptive }\end{array}$ & $\begin{array}{l}\text { The use of YouTube Vlog- } \\
\text { based learning media helps } \\
\text { teachers be more innovative } \\
\text { and create a pleasant } \\
\text { classroom atmosphere for } \\
\text { learning }\end{array}$ \\
\hline 7 & $\begin{array}{l}\text { Hana Sakura } \\
\text { Putu Arga, } \\
\text { Galih Dani } \\
\text { Septiyan } \\
\text { Rahayu, } \\
\text { Ronny } \\
\text { Mugara }\end{array}$ & 2019 & Indonesia & $\begin{array}{l}\text { Knowing the effect of } \\
\text { the preparation of Vlog- } \\
\text { based teaching } \\
\text { materials on improving } \\
\text { cross-cultural skills }\end{array}$ & $\begin{array}{l}\text { Quasi- } \\
\text { experiment }\end{array}$ & $\begin{array}{l}\text { Learning in the } \\
\text { experimental class can } \\
\text { improve cross-cultural skills }\end{array}$ \\
\hline 8 & $\begin{array}{l}\text { Eka Dian } \\
\text { Susanti, Ari } \\
\text { Sapto, Dewa } \\
\text { Agung Gede } \\
\text { Agung }\end{array}$ & 2020 & Indonesia & $\begin{array}{l}\text { Vlog-based ECHA } \\
\text { media was developed to } \\
\text { increase learning } \\
\text { motivation }\end{array}$ & $\begin{array}{l}\text { Research \& } \\
\text { development }\end{array}$ & $\begin{array}{l}\text { Practical and valid media } \\
\text { can increase motivation }\end{array}$ \\
\hline
\end{tabular}

\begin{tabular}{|c|c|c|c|c|c|c|}
\hline \multicolumn{7}{|c|}{ Ethnosciences (6 articles) } \\
\hline 9 & $\begin{array}{l}\text { Okwara Kalu } \\
\text { Okwara }\end{array}$ & 2017 & Nigeria & $\begin{array}{l}\text { Know the effect of } \\
\text { ethnoscience learning } \\
\text { approaches on student } \\
\text { achievement and } \\
\text { interest }\end{array}$ & $\begin{array}{l}\text { Quasi- } \\
\text { experimental }\end{array}$ & $\begin{array}{l}\text { Students who are taught } \\
\text { using the ethnoscience } \\
\text { learning approach get } \\
\text { higher scores }\end{array}$ \\
\hline 10 & $\begin{array}{l}\text { Agnes Amila } \\
\text { W, } \\
\text { Abdurrahman, } \\
\text { Agus Suyatna, } \\
\text { I Wayan } \\
\text { District, } \\
\text { Kartini } \\
\text { Herlina }\end{array}$ & 2018 & Indonesia & $\begin{array}{l}\text { Analyze practicality and } \\
\text { effectiveness } \\
\text { Ethnoscience-based } \\
\text { worksheets are in } \\
\text { progress } \\
\text { student understanding }\end{array}$ & $\begin{array}{l}\text { Quasi- } \\
\text { experimental }\end{array}$ & $\begin{array}{l}\text { The experimental class } \\
\text { using ethnoscience-based } \\
\text { worksheets got an increased } \\
\text { conceptual understanding }\end{array}$ \\
\hline 11 & $\begin{array}{l}\text { Danang } \\
\text { Triasmoro } \\
\text { Adhi, } \\
\text { Sudarmin, }\end{array}$ & 2018 & Indonesia & $\begin{array}{l}\text { Develop instructional } \\
\text { video based } \\
\text { ethnoscience }\end{array}$ & $\begin{array}{l}\text { Research and } \\
\text { development }\end{array}$ & $\begin{array}{l}\text { The instructional video } \\
\text { developed is very suitable } \\
\text { according to BSNP to } \\
\text { increase student knowledge }\end{array}$ \\
\hline
\end{tabular}




\begin{tabular}{|c|c|c|c|c|c|c|}
\hline No & $\begin{array}{c}\text { Writer's } \\
\text { name }\end{array}$ & Year & $\begin{array}{c}\text { Author } \\
\text { Origin }\end{array}$ & Purpose & Method & Findings \\
\hline & $\begin{array}{l}\text { Suharto } \\
\text { Linuwih }\end{array}$ & & & & & \\
\hline 12 & $\begin{array}{l}\text { Sudarmin, W } \\
\text { Sumarni, S } \\
\text { Mursiti, and } \\
\text { SS Sumarti }\end{array}$ & 2019 & Indonesia & $\begin{array}{l}\text { Know the character } \\
\text { profiles innovative and } \\
\text { creative thinking of } \\
\text { students in designing } \\
\text { batik design chemical } \\
\text { after applying the } \\
\text { integrated project } \\
\text { learning model of } \\
\text { ethno-STEM }\end{array}$ & $\begin{array}{l}\text { Deskriptive } \\
\text { qualitative }\end{array}$ & $\begin{array}{l}\text { The learning model } \\
\text { developed can increase } \\
\text { students' cognitive } \\
\text { knowledge, creativity, } \\
\text { innovation, and } \\
\text { entrepreneurial character }\end{array}$ \\
\hline 13 & $\begin{array}{l}\text { FA Adesoji, } \\
\text { NA Omilani, } \\
\text { and OA } \\
\text { Francis }\end{array}$ & 2019 & Nigeria & $\begin{array}{l}\text { Explore the predictive } \\
\text { value of } \\
\text { teacher variable; } \\
\text { cultural value, } \\
\text { experience } \\
\text { and gender and; the } \\
\text { location of the school } \\
\text { under assessment } \\
\text { chemistry teacher } \\
\text { awareness of } \\
\text { ethnoscience practice }\end{array}$ & Descriptive & $\begin{array}{l}\text { Teachers experience, } \\
\text { gender, cultural values and } \\
\text { the location of the school } \\
\text { has contributed significantly } \\
\text { to the awareness composite } \\
\text { chemistry teacher on the } \\
\text { technique of ethnoscience }\end{array}$ \\
\hline 14 & $\begin{array}{l}\text { Eko } \\
\text { Risdianto, } \\
\text { Meli Junia } \\
\text { Dinissjah, } \\
\text { Nirwana, } \\
\text { Muhammad } \\
\text { Kristiawan } \\
\end{array}$ & 2020 & Indonesia & $\begin{array}{l}\text { Find effects } \\
\text { critical thinking skills } \\
\text { after learning with an } \\
\text { ethnoscience-based } \\
\text { learning model } \\
\text { direct instruction }\end{array}$ & $\begin{array}{l}\text { Quasi- } \\
\text { experimental }\end{array}$ & $\begin{array}{l}\text { Application of Ethnoscience } \\
\text { Learning Model } \\
\text { based Direct Instruction } \\
\text { influence critical thinking } \\
\text { skills and motivation of } \\
\text { students }\end{array}$ \\
\hline \multicolumn{7}{|c|}{ Social Media Literacy (11) } \\
\hline 15 & $\begin{array}{l}\text { David } \\
\text { Magolis and } \\
\text { Audra Briggs }\end{array}$ & 2016 & $\begin{array}{l}\text { United } \\
\text { States of } \\
\text { America }\end{array}$ & $\begin{array}{l}\text { Understand student } \\
\text { perspective on SNS } \\
\text { privacy through the lens } \\
\text { of media literacy to } \\
\text { design a media literacy } \\
\text { curriculum }\end{array}$ & $\begin{array}{l}\text { Literature } \\
\text { Review }\end{array}$ & $\begin{array}{l}\text { Students need media } \\
\text { literacy education to help } \\
\text { differentiate what } \\
\text { information is acceptable }\end{array}$ \\
\hline 16 & $\begin{array}{l}\text { Rila } \\
\text { Setyaningsih }\end{array}$ & 2017 & Indonesia & $\begin{array}{l}\text { Describe and } \\
\text { understand the media } \\
\text { literacy model based on } \\
\text { local wisdom in the } \\
\text { community }\end{array}$ & $\begin{array}{l}\text { Exploratory } \\
\text { research }\end{array}$ & $\begin{array}{l}\text { Media literacy acts require } \\
\text { filters in the form of } \\
\text { community local wisdom }\end{array}$ \\
\hline 17 & $\begin{array}{l}\text { Donnell } \\
\text { Probst }\end{array}$ & 2017 & California & $\begin{array}{l}\text { Investigate the } \\
\text { possibility } \\
\text { use social media } \\
\text { literacy education as } \\
\text { part of individual } \\
\text { education plans }\end{array}$ & Descriptive & $\begin{array}{l}\text { There needs to be an } \\
\text { interdisciplinary approach } \\
\text { to social media literacy as a } \\
\text { social and emotional } \\
\text { learning intervention for } \\
\text { students } \\
\text { with autism spectrum } \\
\text { disorders, emotions, and } \\
\text { behavior }\end{array}$ \\
\hline 18 & $\begin{array}{l}\text { Rafiu Ayinla } \\
\text { Suleiman }\end{array}$ & 2017 & Ghana & $\begin{array}{l}\text { Test influence of social } \\
\text { media on student } \\
\text { literacy competency }\end{array}$ & $\begin{array}{l}\text { Quantitative } \\
\text { data were } \\
\text { analyzed } \\
\text { using } \\
\text { descriptive } \\
\text { statistics }\end{array}$ & $\begin{array}{l}\text { Too much time is spent on } \\
\text { social media, and this } \\
\text { affects their academic } \\
\text { performance }\end{array}$ \\
\hline 19 & $\begin{array}{l}\text { Gianna } \\
\text { Cappello }\end{array}$ & 2017 & Italy & $\begin{array}{l}\text { The role of media } \\
\text { technology } \\
\text { accelerate expansion in } \\
\text { audio-visual literacy, } \\
\text { media literacy, media } \\
\text { literacy education, } \\
\text { digital literacy, literacy } \\
\text { information, etc. }\end{array}$ & $\begin{array}{l}\text { Literature } \\
\text { Review }\end{array}$ & $\begin{array}{l}\text { Digital technology is } \\
\text { increasingly attracting } \\
\text { public attention, but a range } \\
\text { of risks and concerns must } \\
\text { be considered }\end{array}$ \\
\hline
\end{tabular}




\begin{tabular}{|c|c|c|c|c|c|c|}
\hline No & $\begin{array}{c}\text { Writer's } \\
\text { name }\end{array}$ & Year & $\begin{array}{c}\text { Author } \\
\text { Origin }\end{array}$ & Purpose & Method & Findings \\
\hline 20 & Joelle Nagle & 2018 & Canada & $\begin{array}{l}\text { Reviews the latest } \\
\text { research on social } \\
\text { media }\end{array}$ & $\begin{array}{l}\text { Literature } \\
\text { Review }\end{array}$ & $\begin{array}{l}\text { Recent research on the use } \\
\text { of Twitter in teacher } \\
\text { education shows many } \\
\text { benefits of using it as an } \\
\text { educational tool }\end{array}$ \\
\hline 21 & $\begin{array}{l}\text { Adebayo John } \\
\text { Oluwaseye } \\
\text { (CLN) \& } \\
\text { Morenike } \\
\text { Kafayat } \\
\text { Oyetola }\end{array}$ & 2018 & Nigeria & $\begin{array}{l}\text { Test information } \\
\text { literacy skills as a } \\
\text { determinant } \\
\text { use of social media } \\
\text { among students }\end{array}$ & $\begin{array}{l}\text { Survey } \\
\text { research }\end{array}$ & $\begin{array}{l}\text { Most of the respondents get } \\
\text { information from Google+, } \\
\text { Twitter, Facebook, } \\
\text { YouTube }\end{array}$ \\
\hline 22 & $\begin{array}{l}\text { Jin-Sik Choi, } \\
\text { Young-Suk } \\
\text { Lee, Je-Sun } \\
\text { Uh, Chul-Jae } \\
\text { Choi }\end{array}$ & 2018 & Korea & $\begin{array}{l}\text { Analyze Media } \\
\text { Information Literacy } \\
\text { level of international } \\
\text { students at the K- } \\
\text { university }\end{array}$ & Survey & $\begin{array}{l}\text { The curriculum has to } \\
\text { educate computer or } \\
\text { internet and media } \\
\text { information literacy of all } \\
\text { students from } \\
\text { "underdeveloped countries." } \\
\text { must be made }\end{array}$ \\
\hline 23 & $\begin{array}{l}\text { Chidozie E. } \\
\text { Nwafor, } \\
\text { Jude O. } \\
\text { Ezeokana \& } \\
\text { Cynthia N. } \\
\text { Onyejiaka } \\
\end{array}$ & 2019 & Nigeria & $\begin{array}{l}\text { Know where social } \\
\text { media and social media } \\
\text { literacy }\end{array}$ & Qualitative & $\begin{array}{l}\text { The need to create literacy } \\
\text { about the possible } \\
\text { consequences that can come } \\
\text { with social media }\end{array}$ \\
\hline 24 & $\begin{array}{l}\text { Khoirul } \\
\text { Anwar, Fitri } \\
\text { Amalia } \\
\text { Shintaswi, } \\
\text { Ferani } \\
\text { Mulianingsih }\end{array}$ & 2020 & Indonesia & $\begin{array}{l}\text { Know the utilization of } \\
\text { media literacy by } \\
\text { teacher's college and } \\
\text { inhibit learning }\end{array}$ & Qualitative & $\begin{array}{l}\text { Teacher trying to adjust to } \\
\text { various media update in } \\
\text { progress }\end{array}$ \\
\hline 25 & $\begin{array}{l}\text { Stefania } \\
\text { Manca, } \\
\text { Stefania } \\
\text { Bocconi, } \\
\text { Benjamin } \\
\text { Gleason } \\
\end{array}$ & 2020 & Italy & $\begin{array}{l}\text { Give the "glocal" } \\
\text { approach to investigate } \\
\text { social media skills } \\
\text { through theoretical lens } \\
\text { composites based on } \\
\text { New Literacy Studies }\end{array}$ & $\begin{array}{l}\text { Literature } \\
\text { Review }\end{array}$ & $\begin{array}{l}\text { Most studies consider } \\
\text { global social media skills, } \\
\text { while only a few have } \\
\text { studied the skills that are } \\
\text { specific to a social media } \\
\text { platform-specific }\end{array}$ \\
\hline
\end{tabular}

\section{The Origin of the Researcher}

The origin of the authors was obtained from the nationality of the authors in the publication of the analyzed articles. The origin of this author is investigated to find out the distribution of countries that often research-related topics. After knowing which countries constantly research Vlogs, ethnoscience, and social media literacy, the analysis is carried out quantitatively by calculating the percentage of the country's contribution to the three topics discussed.

Based on the 25 articles analyzed, Indonesia was the country that was ranked first out of nine countries on the topics of Vlog and ethnoscience. Authors from Indonesia have $75 \%$ for Vlog topics, $67 \%$ for ethnoscience topics, and $18 \%$ for social media literacy topics. Meanwhile, the other eight countries are Turkey, France, Nigeria, Canada, the United States of America, Italy, Korea, and Ghana. The percentage of authors from each article topic is illustrated in Figure 2. 


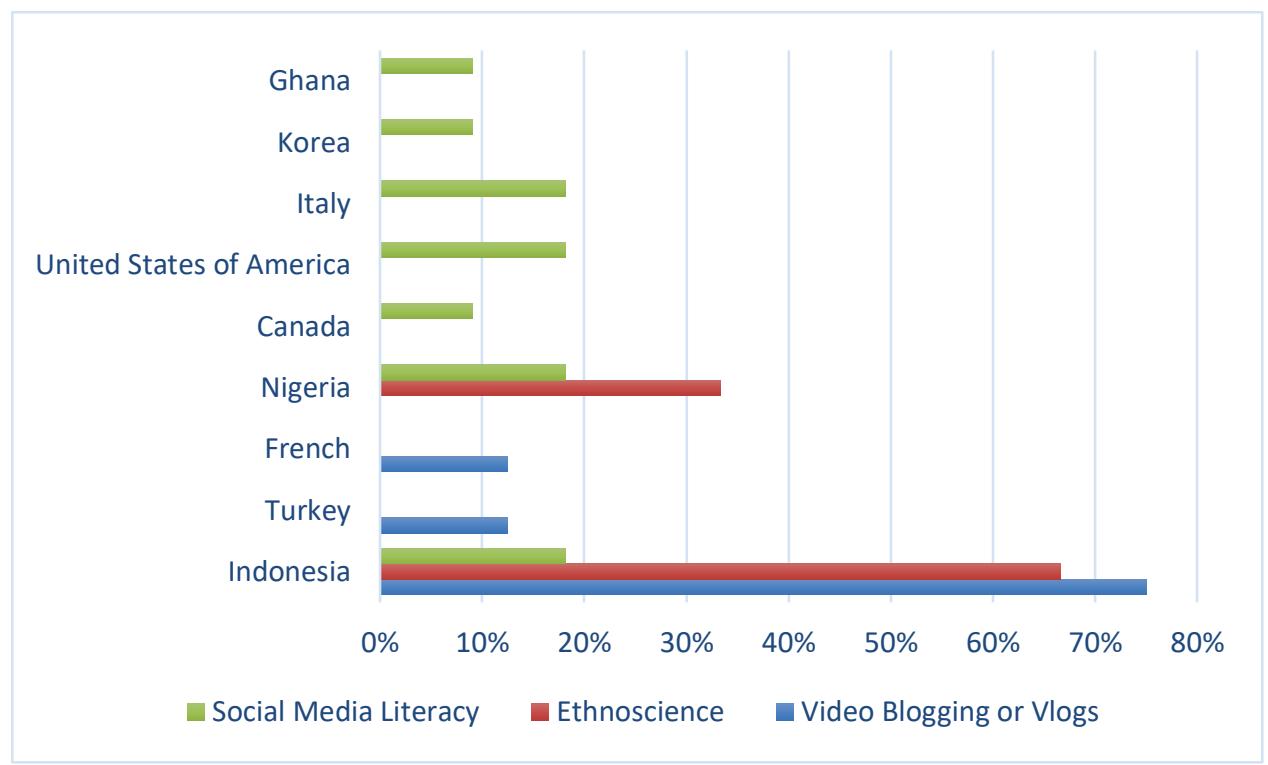

Figure 2. Percentage of authors' origins

Indonesia has a high percentage of authors from each topic because these topics are becoming the latest trend among Indonesian people, especially among researchers. Indonesia was ranked first for ethnoscience and Vlog topics. W et al. (2018), originating from Lampung, is evidence from an Indonesian writer on ethnoscience. Research on the same issue was also conducted by Risdianto et al. (2020), Sudarmin et al. (2020), and Adhi et al. (2018). The variety of local wisdom in Indonesia makes it easy for researchers to dig deeper into the cultures that exist in Indonesia to be appointed as research topics and transformed into scientific science.

Meanwhile, social media literacy in Indonesia has the same percentage as Ghana, Nigeria, Italy, and the United States. This is because social media literacy has not been studied too much. Researchers usually focus more on researching digital literacy or only media literacy, such as research conducted by (Setyaningsih, 2017) and (Anwar et al., 2020). The only difference is that in literacy, Setyaningsih (2017) focuses on social media literacy, whereas Anwar et al. (2020) are still general in media literacy. It is different from Setyaningsih and Anwar, Hibra et al., (2019) in Jombang Indonesia was more interested in finding out the feasibility through the Research and Development method. Sari (2018) in Jambi, Indonesia, also researched the topic of Vlogs to increase motivation and self-confidence; (Arumsari et al., 2019) in Surakarta, Indonesia also conducted Vlog research related to motivation and language skills; (Karamina, 2020) in Semarang, Indonesia utilizing Vlog-based learning media on YouTube; (Susanti et al., 2020) in Malang, Indonesia developed Vlog-based ECHA media to increase learning motivation; and (Arga et al., 2019) in Cimahi, West Java, Indonesia compiled Vlog-based teaching materials. Vlogs on YouTube are becoming a trend among the general public, people are not only interested as Vlog viewers, but many are interested in becoming Vloggers. The trending of Vlogs on YouTube makes Vlogs not only interesting among the general public but also among researchers. Some researchers finally make Vlog a topic in their research.

After Indonesia, Nigeria ranks second on the topic of ethnoscience. The authors who write on ethnoscience topics are 33\% from Nigeria. As research conducted by Okwara \& Upu (2017) shows, the author comes from Nigeria. The same study on ethnoscience was also driven 
by Adesoji et al. (2019), originating from Nigeria. The only difference is that Okwara \& Upu (2017) do it in Benue State, while Adesoji et al. (2019) researched Ibadan, Oyo State. Apart from them, Nigeria also studied social media literacy conducted by Oluwaseye \& Oyetola (2018) in Ibadan and Nwafor et al. (2016) in Awka, Nigeria.

Several countries are also interested in researching the topics of Vlog, ethnoscience, and social media literacy. Research conducted by Fidan \& Debbag (2018) in Bartin, Turkey, assigns students to create a Vlog; Combe \& Codreanu (2016) in France, which focuses on the potential use of Vlogs to develop language speaking skills and intercultural exchange between users. Social media literacy is also becoming a trend in other countries such as (Suleiman, 2017) in Ghana; (Cappello, 2017) in Italy; (Choi et al., 2018) in Korea; (Probst, 2017) in California; (Manca et al., 2021) in Italy and USA; (Magolis \& Briggs, 2016) in the Bloomsburg United States; and (Nagle, 2018) in London, Ontario, Canada.

\section{Research Purposes}

Research objectives are an expression of the goals achieved in a study (Ridha, 2017). Based on the journal review, the writer reveals various purposes according to the target to be completed. The diversity of research objectives was analyzed to find out the similarities and differences in the research objectives of each analyzed article. In each article, the author's purpose of conducting the research is examined more deeply, and from that goal, we can find out how far the contribution of the topic in learning.

Okwara \& Upu (2017) showed that a study on ethnoscience aims to determine the ethnoscience learning approach's effect on students' achievement and interest in Basic Science and Technology. In line with Ulfa (2019) which describes the effectiveness of ethnosciencebased Learning Implementation Plans (RPP) to increase student interest and learning outcomes in additive material, and Wulandari et al. (2018), who researched to know the effectiveness of learning membrane transport with ethnoscience on cognitive learning outcomes and entrepreneurial interest in high school students. Studies on ethnoscience averages examine the association between ethnoscience variables and other variables such as W et al. (2018), who analyzed the practicality and effectiveness of ethno-based student worksheets with increased student understanding; Risdianto et al. (2020) ethnoscience with critical thinking skills; Sudarmin et al. (2020) with the character of creative and innovative thinking. Meanwhile, Adhi et al. (2018) develop ethnoscience combined with instructional videos. Development carried out by Adhi et al. (2018) is an entry point for the connection between ethnoscience and video. In line with research Sudarmin et al. (2018), which uses the scientific direct instruction model with ethnoscience learning videos, it turns out to increase students' interest and critical thinking skills. The variety of videos is very varied, one of which is video-blogging (Vlog). So it is interesting if ethnoscience is juxtaposed with Vlog.

Researchers interested in Vlog's topic, mainly development research, develop Vlog as a learning media product. In line with Hibra et al. (2019), a Vlog created a Vlog to determine the feasibility, student responses, and an overview of learning outcomes after using a Vlog. The same thing was done by Susanti et al. (2020), who developed Vlog-based ECHA media to increase learning motivation. Muzacky \& Prasetya (2019) also created a vlog learning media with the ADDIE development method to determine differences in student learning outcomes. It is not uncommon for researchers to pair Vlogs with learning motivation. Many studies aimed 
at developing Vlogs to increase learning motivation, such as Sari (2018) research, to increase motivation and confidence in speaking English. Research on Vlogs is also often associated with language skills because the characteristic of Vlogs itself is speaking in line with the study conducted by Combe \& Codreanu (2016), which conducted Vlog research to describe and analyze informal learning communication between French language students in America who posted their experiences on YouTube. Because Vlogs are usually posted on YouTube channels, course Vlogs have something to do with social media literacy. However, research on Vlogs in collaboration with social media literacy has never been done. Whereas between Vlogs and social media literacy, of course, it is very closely related.

Research on social media literacy also has multiple research objectives. For example, Nagle (2018) reviews social media in teacher education for teacher pedagogical competence to be critical again in social media, especially Twitter. Probst (2017) also investigated that social media literacy is part of individual educational plans to improve social and emotional learning outcomes. From Nagle and Probst, we can see that social media literacy is very influential in the world of education, especially in the pedagogic competence of teachers. The teacher's ability to manage the learning process is also influenced by how the teacher uses social media wisely. Teachers who are wise in social media by utilizing social media to seek information and discuss with social media residents (netizens) about the learning process can improve the pedagogic competence of teachers both socially and emotionally. In addition, media literacy can also collaborate with local wisdom, as did Setyaningsih (2017). The research conducted by Setyaningsih (2017) shows a link between local wisdom and media literacy, mainly social media literacy. Between ethnoscience and social media literacy, of course, there is a connection because ethnoscience is never far from local wisdom. In this case, social media is a medium to publish local wisdom in a specific area to be introduced by the world quickly and without any time limit. The audience can feel the local wisdom of a space without having to visit the place. So it is crucial to do research collaboration between ethnoscience and social media literacy.

\section{Research Methods}

Method analysis is used to determine the methods used by the author in conducting his research, what methods are often used, and the results when applying these methods to the topics discussed. If the method used by the author is known, we can compare one way with another so that it can be concluded that if using this method, the results will be the same. In addition, from one topic to another, the same techniques used by the author in his research were also analyzed. It could be on the topic of Vlogs utilizing this method, but on ethnoscience, you can also use the same process. Findings like this can later be used as a reference in further research.

In a study conducted by Hibra et al. (2019), Vlog was developed using the 4-D Model, namely Define, Design, Develop, and Disseminate. This 4-D model was also carried out by Adhi et al. (2018) in their research, which developed ethnoscience-based learning videos. In line with research Fitriyani \& Wiyatmo (2017) also developed Vlog learning media with a 4-D model with research subjects in class X MIPA at SMA N 2 Ngaglik. In contrast to Susanti et al. (2020) research, along with the Lee \& Owens development model with data collection techniques used were observation, interviews, material validation, media validation, questionnaires, and tests. Research conducted by Hibra et al. (2019) with Susanti et al. (2020) 
both use the research and development method but differ in their use of the model, namely 4D and Lee \& Owens. Lee \& Owens' model is a research and development model that uses five stages in its development, namely analysis, design, development, implementation, and evaluation (Santosa \& Agustino, 2020).

Research on Vlogs is also researched qualitatively, as did Fidan \& Debbag (2018) and Karamina (2020), who conducted a case study using Vlogs. Combe \& Codreanu (2016) also do the same thing: describe and analyze informal communication using Vlogs; he uses a qualitative data analysis method based on Computer-Mediated Discourse Analysis. The difference lies in the Computer-Mediated Discourse Analysis. CMDA is developed by adopting techniques from a discipline that focuses on language, especially verbal interactions, and can require qualitative or quantitative analysis (Zhu et al., 2019). Research using qualitative descriptive was also conducted by Arumsari et al. (2019) by presenting statistical data. However, the respondents were selected using a purposive sampling technique. The research object as the primary data in this study was video blogging made by students per group and a questionnaire about learning motivation. Data collection was carried out by observing the video presentation and questionnaire on learning motivation. Apart from R\&D and qualitative studies, Vlog has also been researched experimentally like Arga et al. (2019), which used a quasi-experimental method with a non-equivalent pretest-posttest control group design research design.

Okwara \& Upu (2017) also conducted a quasi-experimental, non-randomized, pretest, posttest control group design to determine the effect of learning within the ethnoscience approach in Benu State, Nigeria. W et al. (2018) also used the same method to analyze the effectiveness of ethnoscience-based worksheets and Risdianto et al. (2020) to determine the effect of critical thinking skills with a direct instruction-based ethnoscience learning model. Ethnoscience has also been researched descriptively, as did Adesoji et al. (2019).

Besides being suitable for researching ethnoscience topics, qualitative descriptive methods are also widely used to describe social media literacy. In line with research conducted by Nwafor et al. (2016), Probst (2017), and Anwar et al. (2020). There are also many literature review articles on social media literacy, such as articles from Nagle (2018), Magolis \& Briggs (2016), Manca et al. (2020), and Cappello (2017). In the literature review, the difference lies in the model used to inform the publication identification process, a description of the eligibility criteria, identification of information sources, the data collection process, data items, and the synthesis of existing results using the PRISMA standard (Preferred Reporting Items for Systematic Review and Meta-Analysis) and some are using a phenomenological research approach.

\section{Research Findings}

The findings are the most crucial part, where the findings explain how important the topics are researched. In this section, it is analyzed to find out the results of each article whether the results will have a positive or negative impact. If most articles explain that the results are good, then these topics deserve further research. The results of this study also present in what areas the issue has an impact.

Based on the articles' results and the author's analysis, it was found that interesting Vlogs were developed and declared feasible as educational learning media. Following the research and development carried out by Hibra et al. (2019), Vlog is reported as a learning medium by 
experts in terms of material, the feasibility of media aspects consisting of content and quality objectives, teaching quality, and technical quality, response, and learning outcomes students. Arumsari et al. (2019) also stated that $35 \%$ of students strongly agreed with the learning motivation questionnaire, and $40 \%$ of students agreed, which characterized the existence of a Vlog showing a positive influence as a learning medium. A good response from students to Vlog is directly proportional to the learning motivation of students. Students who give positive answers to Vlogs also show high learning motivation. As a result of this high learning motivation, Arumsari et al. (2019) also explained that students' value of speaking skills was too high. In line with research conducted by Sari (2018) in Jambi, Indonesia; Combe \& Codreanu (2016) in France; and Susanti et al. (2020) in Malang, Indonesia.

In addition to having a positive impact on learning motivation and speaking skills, Vlogs' existence as a learning medium helps teachers be more innovative and create a pleasant classroom learning atmosphere (Karamina, 2020). Moreover, incorporating social, cultural, and norms values into it will make Vlogs a learning medium of interest. Learning with cultural values in it is called ethnoscience integrated learning. Researchers from Nigeria by Okwara \& Upu (2017) stated that students who were taught using the ethnoscience learning approach scored higher in posttest average achievement scores than students conducted using conventional teaching methods. Lampung W et al. (2018) found that the experimental class got an $\mathrm{N}$-gain score of 0.60 or was in the moderate improvement category, while the control class got an $\mathrm{N}$-gain score of 0.34 or lower improvement. The higher $\mathrm{N}$-gain value of the experimental study indicates a positive impact on learning with ethnoscience. Ethnoscience learning can improve students' conceptual understanding. Suppose students can understand the concept of the material. In that case, students' thinking skills will also increase, especially critical, creative, innovative, and entrepreneurial character. In line with Sudarmin, Sumarni, \& Mursiti (2019), the application of the integrated STEM approach to essential oil ethnoscience gave a positive response. They were able to improve student learning outcomes and experiences.

However, Adesoji et al. (2019) showed that teachers' awareness of ethnoscience practices in their teaching area is below expectations because it offers an average score (60.34). Even though a synergistic learning process with today's developments is very much needed (Reffiane et al., 2020). There needs to be an attitude that can make teachers aware of the importance of culture in learning. Setyaningsih (2017) combines media literacy with local wisdom, and he hopes that local wisdom in the local area is better known with media literacy. Thus, the media's role in learning is no longer essential but has become a necessity. So media literacy, especially social media, needs to be improved again. In line with the research of Anwar et al. (2020) that digital media technology has great potential to support the implementation of learning in responding to today's challenges. Schools need to adjust to the development of their digital media technology. This is because digital technology is increasingly attracting tremendous public attention, contributing to strengthening and strengthening media literacy in schools and other educational settings. However, the risks from the media also need to be considered. Thus, social media literacy is indeed critical to be re-examined.

From the analysis of the 25 articles above, there are exciting findings that need to be further developed in a study. Vlogs that we usually watch on YouTube can be developed into a learning medium, and several studies have stated that the media is suitable for use as a learning medium. In addition, Vlogs also positively impact student development, ranging from increased 
learning motivation to skills. Vlogs can also foster a pleasant atmosphere in the classroom and help teachers be more innovative in designing learning activities. If Vlog has collaborated with ethnoscience, it will become a learning media that attract students' attention and the general public. This Vlog with ethnoscience, if uploaded to social media, can be a way of publishing local wisdom and a medium of learning. This can also suppress harmful content on social media by bringing up positive content such as this Vlog with ethnoscience. Therefore, developing Vlogs as learning media with collaboration between ethnoscience and social media literacy is essential.

\section{Conclusion}

Based on the systematic review conducted, it can be concluded that (1) Indonesia was the country that was ranked first out of nine countries on the topics of Vlog by $75 \%$ and ethnoscience topics by $67 \%$, (2) the research aims are on average testing, find and develop these topics with other variables, (3) the research methods used also vary, including descriptive qualitative, quasi-experimental, exploratory, survey, literature review, and $R \& D$, (4) The findings show that these topics are interesting for research because it has a positive effect on learning, increases learning motivation, self-confidence, speaking skills, understanding concepts, and critical thinking skills, innovative, creative to the entrepreneurial character. However, apart from giving positive results, research on these topics also negatively impacts, so it is imperative to do further research. This research is essential because Vlog has not been widely used in learning, so the findings of this research will add to the role of Vlog in learning. Ethnoscience in the form of a Vlog is also interesting because it has a fun and cultural insight. Social media literacy has not been widely studied, so it needs further study. Thus this research will play a role in adding to the importance of Vlog, ethnoscience, and social media literacy in learning science in the era of the industrial revolution 4.0.

\section{Acknowledgment}

The author would like to thank the author's friends who have helped review this article and provide constructive criticism and suggestions until completing this article.

\section{References}

Adesoji, F. ., Omilani, N. ., \& Francis, O. . (2019). Teacher Variables and School Location as Predictors of Chemistry Teachers' Awareness of Ethno Science Practices. Journal of Education, Society and Behavioural Science, 31(1), 1-17. https://doi.org/10.9734/jesbs/2019/v31i130140

Adhi, D. T., Sudarmin, \& Linuwih, S. (2018). The Influence of Ethnoscience-Based Learning Video to Improve Students' Understanding of Green Chemistry in Integrated Science Subject. Journal of Innovative Science Education. https://journal.unnes.ac.id/sju/index.php/jise/article/view/22423/10643

Anwar, K., Shintasiwi, F. A., \& Mulianingsih, F. (2020). Teacher optimization in utilizing media literacy for social science learning in semarang. International Journal of Emerging Technologies in Learning, 15(7), 141-148. https://doi.org/10.3991/IJET.V15I07.13227

Arga, H. S. P. A., Rahayu, G. D. S. R., \& Mugara, R. (2019). Penyusunan Bahan Ajar Berbasis Vlog dalam Meningkatkan Keterampilan Cross Cultural Mahasiswa PGSD IKIP 
Siliwangi. Jurnal Ilmiah P2M STKIP Siliwangi. http://ejournal.stkipsiliwangi.ac.id/index.php/p2m/article/view/1454/839

Arumsari, A., Octaviani, S. K., \& Pravitasari, S. G. (2019). The Implementation of Video Blogging to Improve English Speaking Skill and English Learning Motivation of Eleventh Grade Students. International Journal of English Linguistics, Literature, and Education (IJELLE), 1(2), 59-64. https://doi.org/10.32585/ijelle.v1i2.537

Cappello, G. (2017). Literacy, media literacy and social change. Where do we go from now? Italian Journal of Sociology of Education, 9(1), 31-44. https://doi.org/10.14658/pupj-ijse2017-1-3

Choi, J.-S., Lee, • young-Suk, Uh, S., Choi, J., \& Choi, C.-J. (2018). An Analysis on the Status Quo of International Students' Media Information Literacy in Social Network Environment. Journal of the KIECS, 13(6), 1323-1332. https://doi.org/10.13067/JKIECS.2018.13.6.1323

Combe, C., \& Codreanu, T. (2016). CALL communities and culture - short papers from EUROCALL 2016. CALL Communities and Culture - Short Papers from EUROCALL 2016, 2016(2016), 119-124. https://doi.org/10.14705/rpnet.2016.eurocall2016.9781908416445

David, E. R. (Eribka), Sondakh, M. (Mariam), \& Harilama, S. (Stefi). (2017). Pengaruh Konten Vlog Dalam Youtube Terhadap Pembentukan Sikap Mahasiswa Ilmu Komunikasi Fakultas Ilmu Sosial Dan Politik Universitas Sam Ratulangi. Acta Diurna, 6(1), 93363.

Fidan, M., \& Debbag, M. (2018). The Usage of Video Blog (vlog) in the "School Experience" Course: The Opinions of the Pre-service Teachers (Okul Deneyimi Dersinde Video Günlüğü (vlog) Kullanımı: Öğretmen Adaylarının Görüşleri). Journal of Education and Future.

Fitriyani, L., \& Wiyatmo, Y. (2017). Pengembangan Media Pembelajaran VLog (Video Blogging) pada Materi Usaha dan Energi untuk Menumbuhkan Kemandirian dan Meningkatkan Penguaaan Konsep Fisika Siswa Kelas X SMA Negeri 2 Ngaglik. Jurnal Pendidikan Fisika, 6(5), 427-435.

Forbes, D. (2017). Professional online presence and learning networks: Educating for ethical use of social media. International Review of Research in Open and Distance Learning, 18(7), 175-190. https://doi.org/10.19173/irrodl.v18i7.2826

Hibra, B. Al, Hakim, L., \& Sudarwanto, T. (2019). Development of Vlog Learning Media (Video Tutorial) on Student Materials. Tax at SMK PGRI 1 Jombang. International Journal of Educational Research Review, 435-438. https://doi.org/10.24331/ijere.573945 Irwandani, I., Iqbal, M., \& Latifah, S. (2019). Pengembangan Video Blog (Vlog) Channel Youtube Dengan Pendekatan Stem Sebagai Media Alternatif Pembelajaran Daring. Inovasi Pembangunan: Jurnal Kelitbangan, 135. https://doi.org/10.35450/jip.v7i2.140

Irwandani, I., \& Juariyah, S. (2016). Pengembangan Media Pembelajaran Berupa Komik Fisika Berbantuan Sosial Media Instagram sebagai Alternatif Pembelajaran. Jurnal Ilmiah Pendidikan Fisika Al-Biruni, 5(1), 33. https://doi.org/10.24042/jpifalbiruni.v5i1.103

Jauhari, M. I. (2018). Peran Media Pembelajaran dalam Pendidikan Islam. Journal PIWULANG, 1(1), 54. https://doi.org/10.32478/ngulang.v1i1.155 
Karamina, S. (2020). The Role of Social Studies Teacher in the Use of YouTube Vlog-Based Learning Media. Atlantis Press, 443(Iset 2019), 186-190.

Magolis, D., \& Briggs, \& A. (2016). A Phenomenological Investigation of Social Networking Privacy Awareness through a Media Literacy Lens. Journal of Media Literacy Education, 8(2), 22-34. www.jmle.org

Manca, S., Bocconi, S., \& Gleason, B. (2021). "Think globally, act locally": A glocal approach to the development of social media literacy. Computers and Education, 160(March 2020). https://doi.org/10.1016/j.compedu.2020.104025

Muzacky, A. Y., \& Prasetya, S. P. (2019). Pengembangan Media Pembelajaran Vlog pada Materi Mitigasi Bencana Alam di Kelas XI IPS SMA Negeri Singgahan Kabupaten Tuban. Swara Bhumi, 5(9), 8-12.

Nagle, J. (2018). Twitter, cyber-violence, and the need for a critical social media literacy in teacher education: A review of the literature. Teaching and Teacher Education, 76, 8694. https://doi.org/10.1016/j.tate.2018.08.014

Nwafor, C. E., Ezeokana, J. O., \& Onyejiaka, C. N. (2016). Social Media Literacy as a Panacea to Actualising Family Role in Human Development. https://journals.aphriapub.com/index.php/SSR/article/view/682/664

Okwara, O. K., \& Upu, F. T. (2017). Effect of Ethnoscience Instructional Approach on Students Achievement and Interest in Upper Basic Science and Technology in Benue State Nigeria. International Journal of Scientific Research in Education, 10(1), 69-78.

Oluwaseye, A. J., \& Oyetola, M. K. (2018). Information Literacy Skills and Social Media use by Students in Selected Private Secondary Schools in Ibadan, Nigeria. ... Journal of ..., 1(2), 18-31. http://journals.covenantuniversity.edu.ng/index.php/cjlis/article/view/1151

Prasetyo, B., \& Trisyanti, D. (2019). Prosiding SEMATEKSOS 3 "Strategi Pembangunan Nasional Menghadapi RevolusiIndustri 4.0". Revolusi Industri 4.0 Dan Tantangan Perubahan Sosial, 22-27.

Probst, D. (2017). Social Media Literacy as an IEP Intervention for Social and Emotional Learning. Journal of Media Literacy Education, 9(2), 45-57. https://doi.org/10.23860/jmle-2019-09-02-04

Putrawangsa, S., \& Hasanah, U. (2018). Integrasi Teknologi Digital Dalam Pembelajaran Di Era Industri 4.0. Jurnal Tatsqif, 16(1), 42-54. https://doi.org/10.20414/jtq.v16i1.203

Reffiane, F., Sudarmin, Wiyanto, \& Saptono, S. (2020). Students' behaviour towards etnoSTEM: instruments for students of etno-STEM based science education. Journal of Physics: Conference Series, 1567, 1-4. https://doi.org/10.1088/1742-6596/1567/4/042021

Ridha, N. (2017). Proses Penelitian, Masalah, Variabel dan Paradigma Penelitian. Jurnal Hikmah. http://jurnalhikmah.staisumatera-medan.ac.id/index.php/hikmah/article/view/18

Risdianto, E., Dinissjah, M. J., Nirwana, \& Kristiawan, M. (2020). The effect of Ethno sciencebased direct instruction learning model in physics learning on students' critical thinking skill. Universal Journal of Educational Research, 8(2), 611-615. https://doi.org/10.13189/ujer.2020.080233

Santosa, M. H., \& Agustino, E. (2020). E-Learning-mediated Instruction: Preparing Innovative and Work Ready English Materials for Nursing Assistant Students. Pedagogy: Journal of English Language Teaching, 149-158. 10.32332/pedagogy.v8i2.203

Sari, M. (2020). Pengembangan Vlog (Video Blog) Channel Youtube Berbasis STEM pada 
Materi Laju Reaksi Kelas XI SMA/MA. Journal of Research and Education Chemistry, 2(2), 73. https://doi.org/10.25299/jrec.2020.vol2(2).5725

Sari, P. (2018). Using Vlog in the Youtube Channel as a Means To Improve Students' Motivation And Confidence to Speak English in Intermediate 1 Level of LB-LIA Jambi. International Journal of Language Teaching and Education, 1(1), 38-44. https://doi.org/10.22437/ijolte.v1i1.4596

Setyaningsih, R. (2017). Model Literasi Media Berbasis Kearifan Lokal pada Masyarakat Kampung Dongkelan Kauman Daerah Istimewa Yogyakarta. 118 Komuniti, 9(2), 118 125. http://journals.ums.ac.id/index.php/komuniti/article/view/4520

Sudarmin, S., Mursiti, S., \& Asih, A. G. (2018). The use of scientific direct instruction model with video learning of ethnoscience to improve students' critical thinking skills. Journal of Physics: Conference Series, $1006(1) . \quad$ https://doi.org/10.1088/17426596/1006/1/012011

Sudarmin, Sumarni, W., \& Mursiti, S. (2019). The learning models of essential oil with science technology engineering mathematic (STEM) approach integrated ethnoscience. Journal of Physics: Conference Series, 1321, 1-7. https://doi.org/10.1088/1742-6596/1321/3/032058

Sudarmin, Sumarni, W., Mursiti, S., \& Sumarti, S. S. (2020). Students' innovative and creative thinking skill profile in designing chemical batik after experiencing ethnoscience integrated science technology engineering mathematic integrated ethnoscience (ethnostem) learnings. Journal of Physics: Conference Series, 1567(2). https://doi.org/10.1088/1742-6596/1567/2/022037

Sudarmin, Sumarni, W., Yulianti, D., \& Zaenuri. (2019). Developing Students' Entrepreneurial Characters through Downstreaming Research on Natural Product Learning with Ethnoscience Integrated Stem. Journal of Physics: Conference Series, 1387(1), 1-11. https://doi.org/10.1088/1742-6596/1387/1/012085

Sukesti, R., Handhika, J., \& Kurniadi, E. (2020). Potensi Etnosains Dalam Pembelajaran Fisika Pada Materi Getaran, Gelombang dan Bunyi. SNPF (Seminar Nasional Pendidikan Fisika), O(0). http://prosiding.unipma.ac.id/index.php/SNPF/article/view/1394

Suleiman, R. A. (2017). Effects of Social Media on Student's Literacy Competency in Tamale Technical University - Ghana. Adrri Journal of Arts and Social Sciences. https://journals.adrri.org/index.php/adrrijass/article/view/351/335

Sumarni, W., Faizah, Z., Subali, B., Wiyanto, W., \& Ellianawati. (2020). The urgency of religious and cultural science in stem education: A meta data analysis. International Journal of Evaluation and Research in Education, 9(4), 1045-1054. https://doi.org/10.11591/ijere.v9i4.20462

Suni Astini, N. K. (2020). Tantangan dan Peluang Pemanfaatan Teknologi Informasi dalam Pembelajaran Online Masa Covid-19. Cetta: Jurnal Ilmu Pendidikan, 3(2), 241-255. https://doi.org/10.37329/cetta.v3i2.452

Susanti, E. D., Sapto, A., \& Agung, D. A. G. (2020). Pengembangan Media ECHA (Elaboration, Cover Song, Historycal Content, Audio Visual) Berbasis Vlog Dalam Pembelajaran Sejarah. Jurnal Pendidikan: Teori ..., 326-331.

Ulfa, M. (2019). Efektifitas Rencana Pelaksanaan Pembelajaran (RPP) Berbasis Etnosains Untuk Meningkatkan Minat dan Hasil Belajar Siswa Pada Materi Zat Adiktif. E-Jurnal Pensa, 7(1), 24-28. 
W, A. A., Abdurrahman, A., Suyatna, A., Distrik, I. W., \& Herlina, K. (2018). Practicality and Effectiveness of Student' Worksheets Based on Ethno science to Improve Conceptual Understanding in Rigid Body. International Journal of Advanced Engineering, Management and Science, 4(5), 400-407. https://doi.org/10.22161/ijaems.4.5.11

Wiyanto, Saptono, S., \& Hidayah, I. (2020). Scientific creativity: a literature review. https://doi.org/10.1088/1742-6596/1567/2/022044

Wulandari, P., W.H, E. H., \& Nurwahyunani, A. (2018). Efektifitas Pembelajaran Transpor Membran Bermuatan Etnosains Terhadap Hasil Belajar Kognitif Dan Minat Berwirausaha Pada Siswa Sma. BIOMA Jurnal Ilmiah Biologi, 7(1). https://doi.org/10.26877/bioma.v7i1.2537

Zhu, M., Herring, S. C., \& Bonk, C. J. (2019). Exploring presence in online learning through three forms of computer-mediated discourse analysis. Distance Education, 40(2), 205225. https://doi.org/10.1080/01587919.2019.1600365 